História e Perspectivas, Uberlândia (57): 149-176, jul./dez. 2017

http://dx.doi.org/10.14393/HeP-v30n57-2017-6

\title{
ESCRAVOS SENHORES DE ESCRAVOS. PERNAMBUCO, SÉCULOS XVIII E XIX
}

\section{Robson Pedrosa Costa*}

RESUMO: Entre os séculos XVIII e XIX, a Ordem Beneditina do Brasil construiu um modelo de gestão que permitiu manter a estabilidade quantitativa de seus escravos até 1871, quando libertaram todos os seus cativos. Um dos aspectos que caracterizaram este modelo foi o estímulo dado aos escravos a possuírem escravos, que os utilizavam em suas roças (concedidas pela Ordem) ou na troca pela própria alforria, através do sistema de "substituição". O poder desses escravos-senhores era repassado por meio de herança, como no caso de Micaela, que deixou três escravos para os seus filhos. Outros acumularam grande poder, como Nicolau, possuidor de nove escravos, além de outros bens. Ao todo, encontramos 21 escravos-senhores na documentação analisada. Sem dúvida, esta é uma face da escravidão ainda pouco estudada pela historiografia e este estudo vem a contribuir para trazer à luz novos olhares sobre a sociedade escravista.

PALAVRAS-CHAVE: Escravos senhores de escravos. Beneditinos. Pernambuco.

* Professor do Instituto Federal de Pernambuco (Campus Recife), Doutor em História pela Universidade Federal de Pernambuco. Líder do Grupo de Pesquisa História, Cultura e Trabalho, Linha de Pesquisa Cultura, Trabalho e Controle Social nos Oitocentos. Email: robsonpc@gmail.com. Este artigo é parte do terceiro capítulo de minha tese de doutorado intitulada "A Ordem de São Bento e os escravos do Santo: Pernambuco, séculos XVIII e XIX". Agradeço à Facepe pela concessão de bolsa de doutorado e aos meus orientadores: Marcus J. M. de Carvalho e Suely Creusa Cordeiro de Almeida. Agradeço ainda ao irmão João Cassiano dos Santos, por sua dedicação na preservação de valiosa documentação disponível no Arquivo do Mosteiro de Olinda, além de sua gentileza e disposição durante minha pesquisa. 
ABSTRACT: Between the eighteenth and nineteenth centuries, the Benedictine Order of Brazil built a management model that was able to keep the quantitative stability of their slaves until 1871, when they released all its captives. One of the aspects that had characterized this model was the stimulus provided to the slaves to possess slaves, who used them in their gardens (granted by the Order) or exchange by the liberation through the system "replacement". The power of these slaveholder slaves was transferred through inheritance, as in the case of Micaela, who left three slaves to their children. Others accumulated great power, like Nicholas, owner of nine slaves and other goods. Overall, we found 21 slaveholder slavers in the studied documentation. Undoubtedly, this is a side of slavery that has not been sufficiently researched by historiography and this study is to contribute to bring out new perspectives on the slave society.

KEYWORDS: Slaveholder slaves. Benedictines. Pernambuco.

\section{Introdução}

Entre os séculos XVIII e XIX, a Ordem Beneditina do Brasil construiu um modelo peculiar de gestão escravista, ${ }^{1}$ conseguindo

1 Este conceito foi elaborado a partir do estudo do historiador Rafael de Bivar Marquese (2004), que discutiu as "ideias sobre a administração dos escravos elaboradas nas Américas" entre 1660 e 1860 . O autor explorou os escritos deixados pelos letrados coloniais e também produzidos por senhores que visavam prescrever sobre as melhores formas de governar os escravos. Apesar de utilizarmos o termo modelo, os beneditinos não se preocuparam com a produção de um escrito (código de conduta, manual etc.) a ser compartilhado pelo público geral, como o fizeram religiosos como Antonil, Jorge Benci, Manuel Ribeiro Rocha, Antônio Vieira, entre outros, que visavam orientar os senhores acerca do melhor tratamento a ser dispensado aos cativos. Ao mesmo tempo, consideramos que a política de gestão escravista beneditina reuniu um conjunto de regras próprias voltadas para o bom gerenciamento dos estabelecimentos da Ordem de São Bento em todo o Brasil, servindo de modelo para os diversos mosteiros do país. 
manter a estabilidade do número de escravos até 1871, quando decidiu libertar todos os seus escravos. ${ }^{2}$ Este modelo teria como princípios básicos: o estímulo à formação de famílias (pautadas no casamento cristão e na procriação de vários filhos); o incentivo ao roçado próprio (individual ou familiar); a "moralização dos costumes" (através de preceitos religiosos); a autonomia de cada propriedade rural (geralmente sob a administração de um feitorescravo, sem a presença diária de um monge-administrador); e a miragem da liberdade, por meio de um complexo e bem planejado sistema de alforria. Tudo isso seguindo procedimentos minúsculos de conduta impostos aos seus membros, na tentativa de evitar o assenhoramento de um patrimônio que, em teoria, não pertencia aos monges, mas, sim, ao próprio patriarca São Bento. Sendo assim, os beneditinos seriam apenas administradores de todos os bens que pertenciam na verdade ao santo, incluindo os escravos.

Outro ponto importante refere-se ao conjunto de regras construído no decorrer dos séculos XVIII e XIX para a concessão da alforria. Ao adentrar o cotidiano desta prática, foram encontrados muitos aspectos comuns a outras categorias senhoriais. Porém, o que mais chamou a atenção foram as peculiaridades, que em vários pontos contribuem para comprovar a tese sobre a peculiaridade do modelo de gestão escravista beneditino. Entre essas peculiaridades, destacaremos neste texto o incentivo concedido aos escravos a possuírem escravos.

Antes de adentrar o tema, algumas explicações se fazem necessárias. A Ordem Beneditina do Brasil possuía diversos mosteiros espalhados por todo país. Neste estudo, evidenciaremos a análise dos dados referentes ao Mosteiro de Olinda, localizado na província de Pernambuco, nordeste do Brasil. Os monges desta província administravam inúmeros bens, entre eles quatro

2 Um dia antes (28 de setembro), foi decretada pelo Governo Imperial a Lei do Ventre Livre, que criou uma série de procedimentos para a libertação dos escravos do país de forma gradual e segura. Neste contexto, as Ordens Religiosas foram pressionadas pelo Governo a tomarem medidas semelhantes, já que recebiam benefícios do Estado. Os beneditinos foram os únicos que libertaram todos os seus cativos nesta data. 
propriedades rurais (a fazenda Jaguaribe e os engenhos Goitá, São Bernardo e Mussurepe) e centenas de escravos. No final do século XVIII, o número de cativos chegava a 408, mantendo-se estável até 1866, quando os monges possuíam 350 escravos (a partir desta data, eles iniciaram um processo de libertações em massa) (COSTA, 2013, p. 73-74). ${ }^{3}$ É importante destacar que, devido aos mecanismos criados para estimular o crescimento vegetativo da escravaria, raras vezes recorreram à compra de novos cativos (COSTA, 2013, p. 69).

O referencial teórico-metodológico utilizado dialoga com historiadores que se dedicaram a questões pertinentes às relações entre senhores e escravos, numa perspectiva voltada para o que E. P. Thompson chamou de história vista de baixo. Este autor, que tanto influenciou os estudos sobre escravidão no Brasil, chama a atenção para os discursos produzidos "de cima", que poderiam persuadir o historiador a tomar esta perspectiva como única referência e levá-lo a conceber as camadas subalternas como totalmente dependentes do mandonismo senhorial, desconsiderando as estratégias de resistência dos dominados. Dessa forma, o historiador acabaria colocando "a casa-grande" no "ápice, e todas as linhas de comunicação" convergiriam "para a sua sala de jantar, o escritório da propriedade ou os canis" (THOMPSON, 1998, p. 29-30).

Thompson ajuda a lidar com a documentação produzida, ao longo de dois séculos, por uma instituição que visava disciplinar e vigiar por todos os meios aqueles sob sua tutela, destacando-se os monges e os escravos. Ao nos depararmos com um discurso produzido "de cima", buscamos extrair as "vozes" que vinham "de baixo", fazendo com que se evidenciassem as tensões e os conflitos vivenciados por seus sujeitos. Caso contrário, teríamos incorporado o discurso escravista senhorial. Outros conceitos

3 A visível redução de escravos na segunda metade do século XIX explica-se principalmente por duas razões: a diminuição progressiva do número de monges responsáveis pela administração (de 28 no final do século XVIII para apenas 4) e o aumento do número de alforrias a partir de 1850. 
e concepções produzidos por E. P. Thompson também foram pertinentes a este estudo, como poderá ser percebido ao longo do texto, considerando que sua influência, como dito antes, é marcante sobre a produção historiográfica da escravidão; o que nos levou a dialogar constantemente com suas ideias, mesmo que de modo indireto. ${ }^{4}$

Apesar de tratarmos de um modelo construído por uma instituição, não nos ateremos apenas ao seu discurso, pois destacaremos também as ações e reações dos sujeitos envolvidos no processo, trazendo à tona os embates produzidos no cotidiano das relações escravistas. Na verdade, compreendemos que as práticas do cotidiano contribuem para alterar as estruturas de funcionamento das redes de "vigilância", através dos modos de proceder dos indivíduos e grupos, com suas "astúcias", "táticas", formas "sub-reptícias" contra as imposições dos mecanismos disciplinares da sociedade. Encaramos, assim, o cotidiano como campo da "antidisciplina" (CERTEAU, 1994, p. 41-42), e que os indivíduos - fossem eles monges ou escravos - tinham consciência de suas possibilidades e limitações.5

\section{Um escravo por si}

Um dos juristas mais famosos do século XIX, Perdigão Malheiros, escreveu um importante tratado sobre a escravidão no Brasil, publicado em 1866, em que discutiu, entre outras coisas, os direitos dos cativos. Segundo ele, baseando-se no Direito Romano, "O escravo nada adquiria, nem adquire, para si; tudo para o senhor [...]". "Fosse, direitos reais, desmembrações da propriedade, créditos, legados, herança, posse ainda que sem sciencia e consentimento do senhor [...]." (MALHEIROS, 1866, p. 50-51).

4 Sobre a influência de E. P. Thompson na historiografia brasileira, Cf.: Lara (1995); Neder et al. (1998); Lara; Mendonça (2006); Marquese (2013).

5 Outros autores que fazem parte de meu referencial teórico-metodológico são: Slenes (1997); Levi (1992); Revel (1998); Ginzburg (2006); Davis (1987); Ginzburg (1989). 
"Por exceção", continua o jurista, ao escravo era permitido o pecúlio, que se referia "a tudo aquilo que ao escravo era permitido, de consentimento expresso ou tácito do senhor, administrar, usufruir e ganhar, ainda que sobre parte do patrimônio do próprio senhor". Mas, segundo Malheiros, nenhuma lei no Brasil garantia ao cativo o direito ao pecúlio (situação esta modificada pela lei de 1871). ${ }^{6}$ O mesmo poderia ser dito a respeito da livre disposição sobre qualquer bem, nem em "ato de última vontade, nem a sucessão". Contudo, apesar de não amparados por lei, caso o senhor tolerasse tal pedido, "em vida ou causa mortis", era um fato que deveria ser respeitado (MALHEIROS, 1866, p. 52-53).

A historiografia vem apontando as diversas faces por trás do costume da formação do pecúlio pelos escravos no Brasil, principalmente no que se refere ao acúmulo de certa quantia para se alcançar a liberdade. Vários estudos apontaram que a maioria dos cativos que se alforriaram teve que pagar por suas libertações. Para isso, era necessário que o próprio senhor deixasse abertos certos espaços de subsistência, que garantissem o acúmulo de bens por parte do escravo. O que a historiografia ainda não explorou foi o alcance desta abertura no que diz respeito ao acúmulo de posses que iam além do "simples" desejo de manumissão.

Alguns escravos pertencentes aos beneditinos conseguiram bens para si e para sua família, incluindo entre suas posses outros escravos. Trataremos, a seguir, de três elementos constituintes desta prática nas propriedades beneditinas: a troca de um escravo por outro como pagamento da alforria; a transmissão de herança de um cativo a outro; e os recursos que possibilitaram o acúmulo de certo patrimônio dentro do cativeiro.

Apesar do grande número de estudos que se dedicaram à prática da alforria, poucos evidenciaram uma categoria peculiar

6 A Lei de 28 de setembro de 1871, popularmente conhecida como Lei do Ventre Livre ou Lei Rio Branco, reconheceu, segundo Chalhoub, "uma série de direitos que os escravos haviam adquirido pelo costume e aceitação de alguns objetivos das lutas dos negros" (CHALHOUB, 1990, p. 159-160). 
de manumissão, onde um escravo utilizava como moeda de troca outro cativo que o substituísse. Isso se deve ou à ausência destes casos nas respectivas fontes pesquisadas ou ao número ínfimo encontrado na documentação, representando uma porcentagem muito diminuta, se comparada a outras formas de libertação. ${ }^{7}$

Devemos considerar ainda que, excluindo-se uns poucos trabalhos referentes à manumissão, há uma grande lacuna historiográfica acerca dos escravos como proprietários de outros escravos. Existem algumas menções, mas não encontramos nenhum estudo que tenha se aventurado nessa empreitada de forma mais aprofundada. O que tem crescido é o número de pesquisas que se dedicam aos libertos que conseguiram acumular certa riqueza quando fora do cativeiro e a alguns que chegaram a formar verdadeiras fortunas.

Muitos destes libertos possuíram escravos, mas, em sua grande maioria, não ultrapassaram a posse de mais de seis cativos. A exemplo, podemos citar o estudo de João José Reis, que seguiu a trajetória do liberto Manoel Ricardo. Reis (2016, p. 3) afirma que, de uma lista contendo 304 africanos libertos, apenas 67 possuíam escravos, em sua maioria detentores de um ou dois cativos. Já em seu estudo sobre Domingos Sodré, o autor observou que o africano liberto possuiu apenas quatro escravos ao mesmo tempo (REIS, 2008, p. 298).

Semelhantes resultados encontramos no estudo de Nelson Oliveira (2010, p. 55), que analisou 37 inventários (24 de homens livres e 13 de forros) do final do século XVIII. O pesquisador encontrou apenas um liberto que possuía mais de seis escravos e, entre os livres, somente quatro. Temos ainda a tese de doutoramento de Valéria Gomes Costa (2013, p. 196) sobre os africanos libertos do Recife no século XIX, constatando que, de sua amostra, 56,6\% eram possuidores de cativos, mas a "maioria chegou a ter no máximo dois escravos, corroborando

7 Alguns exemplos de estudos clássicos e recentes que se dedicaram à questão da alforria, mas não evidenciaram a prática da substituição, foram: Paiva (1995); Mattoso (1976); Zero (2009); Lima (2010). 
com a historiografia, que afirma o quanto era alto o custo dessa propriedade".

É importante afirmamos ainda que, mesmo considerando outros estudos sobre a Ordem de São Bento e demais associações religiosas, não encontramos referência a escravos possuidores de escravos, com exceção do estudo de Vanessa Ramos, que encontrou três casos entre suas fontes. ${ }^{8}$ Ao contrário das pesquisas citadas, nossa documentação traz importantes subsídios para investigarmos com profundidade os escravossenhores, como poderá ser constatado ao longo deste texto.

Entre 1793 e 1865, os monges beneditinos concederam alforria para 85 escravos. ${ }^{9} \mathrm{O}$ número maior de libertações ocorreu no contexto de acirramento dos debates emancipacionistas (1866-1870), quando alforriaram 119 cativos. Entre as alforrias onerosas $^{10}$ da primeira fase (1793-1865), 18 escravos ofereceram em troca de sua liberdade outro escravo, caracterizando a prática conhecida como "substituição". Ou como os beneditinos intitulavam: "um escravo por si". Esta estratégia utilizada pelos cativos representou $23,4 \%$ (de 77 casos) do total de libertações onerosas. Se comparados a outros estudos, o numero de casos que apresentam esta prática entre os cativos de São Bento é

8 Dois estudos sobre a Ordem de São Bento que tiveram como objeto de pesquisa os seus escravos não encontraram tal peculiaridade: Piratininga Júnior (1991); Pacheco (2010). Outros estudos que tocam na questão da posse de cativos pela Ordem Beneditina e Carmelita, mas sem evidenciar aquela prática: Tavares (2007); Souza (2007); Souza (2011); Molina (2006); Araújo (2007).

9 Os escravos precisavam seguir um procedimento minucioso para alcançar a liberdade. Com a permissão do Abade, faziam um pedido por escrito e encaminhavam ao Conselho Beneditino. Teoricamente, o pedido só poderia ser votado com a presença do Abade Geral, quando em visita ao mosteiro. Decidido através de "favas brancas ou pretas", decidia-se pela alforria ou não. Encontramos apenas dois cativos que tiveram seus pedidos reprovados. Apesar do rigor do processo, a grande maioria dos escravos teve que pagar por sua liberdade.

10 Ou seja, aquelas em que o cativo dava algo em troca por sua liberdade (dinheiro, tempo de serviço ou substituição). 
surpreendente, já que alcança uma porcentagem bastante elevada no cômputo das alforrias onerosas.

Stuart Schwartz (2001, p. 205-206), num montante de 1.650 cartas de alforria, encontrou apenas 18 casos, representando $3 \%$. Peter Eisenberg (1989, p. 282-283), analisando 2.347 cartas de liberdade, encontrou apenas 2 casos. Márcio Soares (2006, p. 155) encontrou, nas mais de 600 alforrias analisadas, apenas 8 casos de substituição. Kátia Almeida (2006, p. 51-51), 33 destes casos, representando apenas $4,4 \%$ das alforrias pagas de sua amostra. Tatiana Lima (2004, p. 76), entre as 456 alforrias analisadas, apenas 2 escravos utilizaram a substituição como forma de pagamento. Vanessa Gomes Ramos (2007, p. 34) encontrou, no conjunto de 370 registros de liberdade, apenas três casos de troca.

O estudo que dedicou mais atenção a esta prática foi produzido por Mieko Nishida (1993, p. 256), referente às alforrias em Salvador, entre 1808 e 1888. Num universo de 3.516 cartas de liberdade, além de outras fontes (testamentos de forros e registros de compra e venda), a autora encontrou 35 casos de substituição. Dado o grande número de alforrias que analisou, esta categoria representou apenas $1 \%$ de todas as manumissões e $2,63 \%$ das autocompras (pagas).

Como visto, mesmo em estudos em que o número de substituições chegou a 33 (ALMEIDA, 2006) ou 35 casos (NISHIDA, 1993), estes tiveram uma representação diminuta no cômputo geral dos dados utilizados pelos respectivos autores. Chegaram a representar, respectivamente, $4,4 \%$ e $2,63 \%$ das manumissões pagas.

Logo, fica evidente que o modelo de gestão escravista beneditino previa este mecanismo de substituição com uma importante ferramenta para a manutenção da estabilidade de sua escravaria. Isso pode ser explicado pelo fato de que a aquisição de um novo escravo vindo do mercado (considerado "estrangeiro", desconhecido e não aculturado), poderia trazer certos inconvenientes, como possíveis conflitos internos e a necessidade de prepará-los para o trabalho no campo ou em alguma especialidade, como destacou Mary Karasch (2000, p. 448). 
Neste sentido, os beneditinos investiam em cativos que demonstrassem habilidades artesanais, como pedreiros, carpinas, oleiros etc., além de atividades mais artísticas, como música, o que demonstra a preocupação destes monges com o trabalho especializado. Considerando que a maioria dos escravos em posse de cativos já residia nas propriedades dos beneditinos há certo tempo, trabalhando ao lado de seus senhores, isso pode ter contribuído para que aprendessem o ofício de seus proprietários, além de passarem a compreender melhor as peculiaridades de ser um "escravo do Santo".

Um dado interessante a ser destacado é que, após 1850, a prática da substituição se tornou rara entre os cativos de São Bento. Depois de 1849, só encontramos mais uma alforria utilizando a substituição como pagamento, e remonta a 1869, não contabilizado entre os 18 casos mencionados (referentes à primeira fase de nosso estudo: 1793-1865). Logo, a concentração das substituições até a data do fim do tráfico de escravos nos faz pensar em algumas questões.

Primeiramente, como apontou Maria Inês Oliveira Cortez (1988, p. 41), entre o final do século XVIII e primeiras décadas do século XIX, o "incremento do tráfico de escravos" possibilitou aos proprietários a aquisição de cativos a um preço menor, devido ao aumento da oferta no mercado durante este período. Segundo a autora, isso explicaria o alto índice de posses de escravos por libertos neste contexto. O mesmo pode ser pensado para os escravos proprietários que perceberam a importância de possuir cativos a seu serviço. Mas, diferentemente dos libertos, muitos escravos utilizavam suas posses para juntarem a quantia necessária para libertar a si mesmos ou um parente, ou utilizá-los diretamente como moeda de troca.

Todavia, após o fim do tráfico negreiro, o acesso a mão-deobra não possuía a mesma facilidade que em tempos anteriores. As áreas dominadas pelas grandes lavouras começavam a drenar para suas fazendas um número cada vez maior de cativos pertencentes aos pequenos proprietários, inclusive de outras regiões (MATTOS, 1998, p. 33-34). A posse de escravos começou 
a se tornar um privilégio de poucos. E os escravos senhores de escravos perceberam as mudanças.

Isso não quer dizer que estes cativos deixaram de ser senhores, mas perceberam, possivelmente, que seria mais lucrativo permanecerem com suas posses do que realizarem uma troca pela liberdade. Com a diminuição do número de cativos decorrente do fim do tráfico, as possibilidades de juntar mais dinheiro com o aluguel ou na realização de outras atividades remuneradas se ampliaram (através de seu trabalho e/ou de seu escravo), levando os cativos beneditinos a dar preferência ao pagamento da alforria em dinheiro. Mas isso é apenas uma hipótese.

Outros autores também perceberam essa concentração de substituições no período anterior ao término do "infame comércio". Kátia Almeida constatou que as 33 substituições que analisou se referiam ao período anterior a 1850, "período de tráfico aberto, quando os cativos tiveram mais oportunidades de adquirir outro cativo, sobretudo aqueles de origem africana recém-chegados, que custavam menos do que um escravo especializado ou já ladino". Desse montante, 12 eram de origem africana, 7 nascidos no Brasil e 14 não identificados (ALMEIDA, 2006, p. 57).

Alguns autores também evidenciaram a predominância de africanos entre os cativos utilizados nas substituições. Segundo Márcio Soares (2006, p. 155, nota 40), as 8 trocas que analisou tinham origem africana. Já no estudo de Mieko Nishida (1993, p. 256), dos 35 forros nesta categoria, 24 haviam nascido na África, contra apenas 3 do Brasil. Outros 8 não tiveram sua origem revelada. No nosso estudo, dos 18 casos de substituições, apenas 2 revelam a origem de suas posses, ambos de "nação" angola. Os demais não revelam origem ou cor, com exceção de "um negro para todo serviço", que pode indicar não necessariamente a cor, mas sim, a condição escrava. ${ }^{11}$

Além das questões até aqui apontadas, uma nos intrigou

11 Para uma discussão sobre as classificações raciais no Brasil, ver: Santos (2005, p. 115-137). 
ainda mais, ao nos depararmos com esta prática como parte dos mecanismos de manumissão dos escravos de São Bento. A substituição seria uma contrapartida dos próprios escravos ou uma exigência dos beneditinos para evitar o esvaziamento de suas senzalas? Sem dúvida alguma esta prática representou um dos elementos constituintes do modelo de gestão escravista construído pela Ordem de São Bento de Pernambuco. Isso porque, apesar do número de casos ser inferior ao pagamento em dinheiro, os escravos tinham a opção, estimulada pelo Conselho, em trocar sua liberdade através da substituição.

Dos 18 pedidos analisados, 5 aparecem claramente como exigência dos monges para a respectiva permuta. ${ }^{12}$ As expressões que demonstram tais iniciativas trazem a seguinte redação: "mediante o preço em que fosse avaliada ou em troca de outro escravo de igual valor"13; "500 mil reis ou um escravo a contendo"; "o Conselho determinou que fosse dado uma escrava a nosso contendo ou o seu valor". ${ }^{14}$

Contudo, foram os escravos que na maioria das vezes propuseram a substituição: 13 casos. As expressões que simbolizam tais pedidos podem ser assim exemplificadas: "dando um escravo por si"; "oferecendo em seu lugar"; "oferecendo por si". Outras duas expressões bem exemplificam a iniciativa dos escravos. Em 1798, André Ribeiro, pedindo a liberdade para sua filha, ofereceu uma escrava Angola como pagamento. O Conselho "deveria julgar a utilidade ou inutilidade desta troca, o que foi aprovado". ${ }^{15}$ Feliciana do Espírito Santo, em 1816, oferecia ao

12 A documentação referente às alforrias se encontra transcrita nos Manuscritos do Arquivo do Mosteiro de São Bento de Olinda, publicados na Revista do Instituto Arqueológico, Histórico e Geográfico Pernambucano, v. XLII, 19481949 (1952). São atas de reuniões do Conselho Beneditino, formado pelo Abade e demais monges do Mosteiro, entre 1793 e 1875. Para facilitar a referência a esta fonte, indicaremos na nota de rodapé a data e a página localizada na referida revista, precedida do termo "Manuscritos".

13 Manuscritos (25 de setembro de 1845, p. 180-181).

14 Manuscritos (28 de setembro de 1798, p. 138).

15 Manuscritos (22 de agosto de 1798, p. 242). 
Mosteiro (em troca de seu filho) "um moleque de nome João de nação Angola". O Conselho "resolveu que desse o escravo que oferecia". ${ }^{16}$

Não é possível responder quando e como se iniciou esta prática entre as manumissões beneditinas. O certo é que parecia ser um bom negócio para os dois lados. Para os monges, evitar os possíveis transtornos na compra de um escravo desconhecido no mercado escravista poderia ser uma opção alternativa. Além disso, muitos cativos conseguiam valores diminutos para sua liberdade, por motivos diversos (bons serviços, doença etc.), ao passo em que a troca nunca seria por um escravo que não estivesse apto ao trabalho, ou seja, que não fosse "útil" à Religião Beneditina. Mas um bom negócio também para os escravos, pois muitos conseguiram seus cativos através de heranças, deixadas por parentes que haviam conseguido acumular alguns bens dentro do próprio cativeiro beneditino, ou oferecidos por familiares desejosos por sua liberdade, como veremos mais adiante.

Poderíamos considerar ainda que em alguns casos os escravos tenham comprado um cativo só para aquele fim, ou seja, para satisfazer a exigência do Mosteiro, a exemplo do que afirma Schwartz (2001, p. 205-206): "O futuro liberto ou intercessor adquiria um escravo do mesmo valor, que era então apresentado ao senhor como substituto". Mas não acreditamos que essa tenha sido a regra. Isso porque a posse e manutenção de escravos pelos cativos beneditinos parece ter sido, se não comum, pelo menos possível, como veremos ao longo deste artigo.

Acreditamos também que, quando um escravo realizava tal permuta, possivelmente não estava se desfazendo de todo o seu patrimônio, pois seria pouco prudente abrir mão de um cativo para viver precariamente na liberdade. É possível que os escravos que possuíssem apenas um cativo tenham optado em juntar o dinheiro para a manumissão, pois, uma vez libertos, poderiam utilizar o trabalho de seu cativo para sobreviver. Como a grande maioria dos alforriados continuava nas terras beneditinas (muitos, inclusive,

16 Manuscritos (14 de maio de 1816, p. 246). 
sem pagar foro), ter um escravo à sua disposição significava um importante salto como homem "livre".

Outro ponto a ser destacado é que o substituto do alforriando não precisava corresponder, necessariamente, aos mesmos atributos físicos ou etários dos requerentes. Mas, evidentemente, existia algum tipo de "cálculo" que os monges realizavam para não perder na hora da troca. Em alguns casos, existia alguma equivalência: Feliciana Camila, mãe de Francisco, de 12 anos, deveria entregar ao Conselho, como pagamento da liberdade de seu filho, "um moleque de 12 ou 14 anos". ${ }^{17}$ Também aparecem expressões que buscam valorizar a capacidade dos cativos colocados em troca: "um negro [ou negra] para todo o serviço"; ou, como apelara Alexandre, que pretendia dar por si um "escravo que melhor que ele" pudesse "servir e ser útil à Religião no trabalho da enxada". ${ }^{18}$

Devemos destacar ainda a predominância feminina entre os escravos senhores. Entre os 18 casos, 10 correspondem a mulheres pedindo sua liberdade (ou de seu filho) em troca de outro cativo, enquanto os homens somaram 8 dos pedidos. A diferença é bem pequena, mas aponta novamente para presença da mulher cativa como importante papel no processo de manumissão e como proprietária de escravos. Este é um dado que corrobora outros estudos que investigaram a vida dos escravos após a manumissão.

Carlos Eugênio Soares (2010, p. 89) também destacou a predominância das mulheres libertas sobre os homens como proprietárias de escravos. Sheila Faria (2000, p.86), em seu estudo sobre as mulheres forras em São João del Rei (Minas Gerais, 1774-1806), constatou que "homens ‘brancos' e mulheres forras foram os que detiveram as condições mais favoráveis de serem possuidoras dos maiores conjuntos de bens do período escravista".

Outro importante dado a se destacar refere-se ao papel

17 Manuscritos (28 de setembro de 1798, p. 147).

18 Manuscritos (30 de agosto de 1793, p. 237-238). 
da família nos casos de substituição. Dos 18 casos, 12 estão relacionados a arranjos familiares. Dois pais ofereceram escravos em troca da liberdade de suas filhas, assim como duas mães. Podemos citar ainda Quirino, que intercedeu por sua esposa, e Joana, por seu marido.

Umbelina é um dos casos mais interessantes. É a única que, na mesma petição (1809), pede a liberdade para si e para sua filha, chamada Maria. Na primeira proposta, ofereceu como pagamento da sua libertação "um negro para todo o serviço", e, para sua filha, "uma negrinha". No final, preferiu pagar 50 mil reis pela alforria de sua filha. ${ }^{19} \mathrm{Ou}$ a "negrinha" não satisfez as exigências do Conselho (o que não aparece na Resolução) ou Umbelina preferiu ficar com a escrava ao invés de pagar um valor relativamente baixo, se comparado aos possíveis ganhos com a posse de um cativo. Teria ela outros escravos? Infelizmente, não temos a resposta.

Considerando os dados até aqui apresentados e os números gerais sobre os pedidos de alforria, fica fácil concluir que o papel da família escrava no processo de libertação no interior das propriedades beneditinas foi crucial. E, como podemos perceber, a estratégia da substituição foi destacadamente um atributo quase familiar. Mieko Nishida (1993, p. 257) também percebeu a importância da família entre estes casos. A autora afirma que apenas duas cartas revelaram como os escravos haviam conseguido seus substitutos e, em ambos os casos, houve a intervenção de parentes, que ofereceram seus cativos em troca da liberdade de seus familiares. Este ponto fica ainda mais evidente quando observamos outros casos em que aparecem escravos senhores de escravos, como veremos a seguir. As famílias, nas propriedades beneditinas, tiveram um amplo leque de possibilidades de construir e manter um patrimônio próprio, incluindo cativos.

19 Manuscritos (18 de janeiro de 1809, p. 244). 


\section{Negócios de família}

Dois casos, que não estão diretamente relacionados com processo de manumissão, nos dão uma boa dimensão do poder de posse que alguns escravos possuíam dentro das propriedades beneditinas e sua relação com a família. O primeiro caso refere-se à escrava Micaela, que morreu no início de junho de 1811. Acativa havia deixado alguns bens a serem divididos entre seus herdeiros. Entre seu patrimônio estavam alguns escravos. Um deles, João Vieira, de 50 anos de idade, havia prestado bons serviços à "Religião até o final daquele ano", por isso decidiu o Conselho conceder-Ihe a liberdade. Os beneditinos se comprometeram a dar o valor do dito João Vieira aos respectivos herdeiros, "filhos da defunta", assim como "para eles se tirando de tudo a terça parte para o sufrágio" dela. ${ }^{20}$

Um mês depois, a escrava Maria das Candeias, cativa pertencente à "defunta" Micaela, acabou incorporada ao patrimônio dos beneditinos, que decidiram ficar com ela mediante $o$ pagamento de seu valor aos respectivos herdeiros. ${ }^{21}$ Percebemos, assim, que os monges também se utilizavam do trabalho desses cativos, possivelmente pagando a seus escravos-senhores os respectivos valores pelas atividades desempenhadas.

O segundo caso refere-se ao escravo José Vieira, que teria morrido em janeiro de 1817 , deixando uma dívida de $33 \$ 000$ a diversas pessoas. Mas, como havia deixado "uma negra", avaliada em 70 mil reis, "a qual de nada servia à Religião, por não ser de serviço", ficou acertado que um irmão do defunto pagaria o dito valor pela escrava. O Conselho votou a favor da venda, firmando

20 Manuscritos (Junho de 1811, p. 156). Segundo Sandra Graham (2005, p. 65): "O direito brasileiro, seguindo o português, especificava que dois terços dos bens de uma pessoa ou de um casal deveriam ser divididos em partes iguais entre filhos ou netos ou, caso não houvesse herdeiros descendentes, os bens reverteriam para os pais ou avós. A pessoa podia dispor do outro terço como bem quisesse [...]; e, se não houvesse herdeiros necessários, a pessoa podia deixar todo o espólio para um herdeiro de sua escolha".

Manuscritos (05 de julho de 1811, 156-157). 
que com o dinheiro se pagasse as ditas dívidas e o que sobrasse fosse distribuído aos filhos do defunto, obrigando-os a dizer-lhe "algumas missas" em nome do falecido. ${ }^{22}$

Como vimos anteriormente, legalmente o escravo não possuía qualquer direito de posse (até 1871) sobre bens que por ventura tivesse conseguido acumular, muito menos deixá-los como legado para outras pessoas após a sua morte. Todavia, aos senhores era facultado permitirem tais práticas. Segundo Stuart Schwartz (2001, p. 101), "a posse de bens era amplamente reconhecida porque proporcionava tranquilidade à administração do sistema escravista".

Foi o que aconteceu nas propriedades beneditinas. Os monges poderiam livremente dispor dos bens deixados pelos cativos que morriam, mas preferiram, possivelmente por princípios religiosos e até mesmo como parte de sua política de "paz nas senzalas", conceder tais direitos aos escravos. Lembramos que o modelo beneditino era fortemente influenciado pelos preceitos religiosos, pautados principalmente nas Regras do Glorioso Patriarca. Por isso, amparar seus servos era um dever não apenas senhorial, mas também cristão. Mesmo quando havia algum interesse em respectivo escravo deixado pelo "defunto", havia a preocupação em conceder aos herdeiros a parte que lhes cabia, como nos casos de Micaela e José Vieira. São casos como esses que nos ajudam a compreender (ou pelo menos refletir) a complexidade das relações escravistas.

E uma importante reflexão seria sobre as possíveis estratégias utilizadas pelos escravos para juntar dinheiro suficiente para sua subsistência (e de sua família) e ainda comprar um cativo (ou vários). Adentraremos esta questão para melhor compreender a dinâmica interna das propriedades escravistas de São Bento. Vários autores destacaram as possibilidades abertas dentro do próprio cativeiro para acumularem pecúlio, inclusive no meio rural, onde escravos juntavam dinheiro adquirido através de suas "agências" (GOLDSCHMIDT, 2010, p. 120-121).

22 Manuscritos (17 de janeiro de 1817, p. 164). 
Os senhores reconheciam a importância de permitir certas práticas que conferissem aos cativos alguma renda. Até porque muitos proprietários se beneficiavam dos "negócios" abertos por seus escravos ou cativos da vizinhança. Como já havíamos afirmado, os beneditinos sempre preparavam escravos para a realização de trabalhos especializados, como pedreiro, carpinteiro, jangadeiro. Há indícios de que estes cativos realizavam trabalho extra e conseguiam juntar certas quantias. O escravo Thomé ladrilhou, em um domingo, a casa de uma liberta (ex-escrava da Ordem) moradora na propriedade de Jaguaribe e recebeu por seu serviço um "patacão ${ }^{23}$ e uma garrafa de vinho", pagos pelo Fr. Filipe, administrador da fazenda. ${ }^{24}$ Outras práticas, como pequeno comércio de doces, produtos agrícolas etc., poderiam incrementar a renda dos cativos de São Bento. Mas havia ainda outras práticas, nem sempre lícitas.

O Fr. Galdino, em seu relatório trienal (1848), destacou a sua grande preocupação com a prostituição. Segundo este Abade, muitas escravas moças viviam deste meio, em busca de seu sustento e de se vestirem "mais comodamente". ${ }^{25} \mathrm{O}$ Fr. Manoel da Conceição Monte, em 1863, destacou o importante trabalho realizado em seu governo, casando vários escravos das diversas propriedades, evitando assim o concubinato e a prostituição. ${ }^{26}$

Apesar da preocupação dos monges, a prostituição garantia,

23 Moeda de prata.

24 Processo Crime: Autora: Rufina Maria Manoela. Réu: D. Abade do Mosteiro de Olinda Fr. Manoel d Conceição Monte. 1862. Arquivo do Museu de Igarassu, seção de Manuscritos, Série: Irmandades Religiosas, Cx.4: São Bento de Jaguaribe.

25 Estados do Mosteiro de São Bento (1842-1845). Os Estados são relatórios trienais produzidos pelos Abades sobre o período em que administraram o respectivo Mosteiro. Consultamos tanto os Estados do século XVIII (fotocópias dos originais que estão sob a tutela do Arquivo Distrital de Braga, Portugal, e disponibilizados no Arquivo do Mosteiro de Olinda) e os do século XIX, transcritos nos Manuscritos publicados na Revista do Instituto Arqueológico, Histórico e Geográfico Pernambucano, v. XLII, 1948-1949 (1952).

26 Estados do Mosteiro de São Bento (1860-1863). Manuscritos (1952). 
a muitas cativas, oportunidades para a subsistência e, quem sabe, para acumular dinheiro para a alforria. Sheila Faria destaca que "as escravas dedicadas ao comércio e [...] à prostituição foram as que mais condições tiveram de pagar por sua liberdade". Segundo a autora, "estavam elas, portanto, triplamente estigmatizadas na sociedade que as cercava: pela cor da pele, relacionada à escravidão, pelo 'defeito mecânico', condição vil, e pela prostituição, repúdio religioso” (FARIA, 2000, p. 81).

Porém, acreditamos que, por se tratarem de propriedades rurais, a principal fonte de recursos dos escravos beneditinos foi a roça própria. Esta era uma prática antiga, encontrada em várias regiões do Brasil escravista. Stuart Schwartz (2001, p. 99) destaca que muitos escravos utilizavam os dias livres que Ihes eram concedidos (domingos, feriados religiosos e dias de descanso) para produzir em suas próprias roças, complementando sua dieta com produtos de suas hortas. Além disso, poderiam vender o excedente "nos mercados locais ou ao proprietário", guardando "o dinheiro ganho para fazer compras ou poupar para acabar comprando a própria liberdade, ou de um ente querido".

E novamente o papel da família se destaca. A constituição de laços familiares dentro do cativeiro poderia proporcionar ao escravo conseguir de seus senhores maiores privilégios em relação aos cativos solteiros. Entre os prêmios, estavam um espaço de moradia especial para os casados (mesmo que dentro da senzala) e, claro, as roças. Estas possibilitavam aos cativos realizarem negócios com a vizinhança, vendendo e comprando produtos necessários à subsistência da família. Segundo Slenes (1999, p. 196-197), "a renda monetária proveniente de todas estas fontes, além de ampliar as possibilidades de 'consumo' e, dessa forma, ajudar a viabilizar o projeto de vida e redes de solidariedade dentro da escravidão, também podia possibilitar poupança".

Para o autor, poupar poderia significar duas possibilidades abertas através do acúmulo de recursos com a roça e a criação de animais. De um lado, a poupança poderia ser utilizada como uma "garantia da sobrevivência no futuro, em dias difíceis". Ao mesmo tempo, juntar dinheiro fazia parte do projeto de muitos daqueles 
que buscavam sobreviver dentro dos limites da escravidão, acumulando recursos suficientes que lhes permitissem "a compra da liberdade" (SLENES, 1999, p. 196-197).

Evidentemente que o acesso a lavoura própria fazia parte das estratégias senhoriais para manter os escravos sob controle. Para aqueles que percebiam alguma possibilidade de "sucesso" sem precisar enfrentar abertamente o senhor, poderia ser um bom negócio desfrutar de certos espaços abertos dentro do cativeiro. "Sucesso", como nos dizem Florentino e Góes (1997, p. 173), "naquela sociedade incrivelmente injusta, não precisava ser tanta coisa. Comida, descanso, um pouco de sossego e, se possível, roçados, alguns dias livres, divertimentos e família".

Nicolau foi um caso à parte. Ele havia se beneficiado do cargo de feitor, destinando para si grande parte das roças que deveriam ser distribuídas a outros cativos, empregando parte de seus escravos (num total de nove) no "serviço da enxada", obtendo lucros em detrimento dos outros. ${ }^{27} \mathrm{O}$ escravo-feitor (e senhor) havia acumulado poder e bens, como gado, cavalo e terras fora das propriedades beneditinas. ${ }^{28}$

Porém, nem sempre a estratégia senhorial trazia os resultados esperados. Segundo Fr. José Botelho, o escravo Júlio recebeu "uma terra maneira e boa" para seu sustento. Todavia, o cativo tinha dificuldades para formar alianças, e não conseguia um só parceiro para dividir a roça. Sem raízes fincadas, sem "amarras" familiares e, principalmente, sem a rede protetora necessária para uma subsistência satisfatória e, até mesmo, para a liberdade, Júlio utilizou a tática senhorial contra seus algozes, "ajuntou toda a sua roupa em um saco" de farinha e fugiu. ${ }^{29}$ Mas esta não foi a regra. A grande maioria ficou mesmo no cativeiro, jogando de acordo com as regras beneditinas, jogando com as armas disponíveis.

27 Manuscritos (Março de 1822, p. 169).

${ }^{28}$ Sobre esse escravo-senhor, cf.: Costa (2017).

29 Processos escravos, 1831-1871 (09 de setembro de 1863). Documentação de natureza diversa, reunindo fontes sobre a escravidão, organizada em dois volumes e localizado no Arquivo do Mosteiro de Olinda. 
Neste sentido, a Ordem de São Bento parece ter dado uma atenção especial à questão do roçado. Mateus Ramalho Rocha (monge beneditino), em seu estudo sobre os beneditinos do Rio de Janeiro, confirma esta prática, afirmando que os escravos da Ordem "possuíam pequenos lotes de terras nos quais habitavam e retiravam sua subsistência e a de sua família" (ROCHA, 1991 apud RAMOS, 2007, p. 175). Esta prática ocorreu de forma mais evidente nas terras de Jaguaribe, por se tratar de uma fazenda destinada ao abastecimento do Mosteiro. Através da venda de excedentes para os próprios monges e possivelmente para os vizinhos, os escravos de São Bento conseguiram construir uma importante rede de negócios que incluía diversas atividades, inclusive a aquisição de escravos.

\section{Considerações finais}

Qual o significado, para um cativo, ser proprietário de escravos? A questão não é nada fácil de responder. Até porque a carência de estudos sobre o tema dificulta maiores interpretações. O que temos em mãos são os estudos sobre os egressos do cativeiro e os recursos que acumularam como libertos. Segundo Carlos E. Soares (2010, p. 89), "ter escravos na Bahia da primeira metade do século XVIII era algo absolutamente normal, e os egressos da escravidão ambicionavam - como todos na sociedade - a propriedade de pelo menos um cativo".

Para Maria Inêz Cortez de Oliveira (1988, p. 41), "a vida de cativeiro ensinara ao liberto que ser livre era ser senhor e ser senhor era possuir escravos que trabalhassem para si. Tal era a verdade do escravismo". E continua: "não havia para o liberto, fosse africano ou crioulo, nenhum constrangimento na assimilação desta verdade, especialmente quando as rivalidades étnicas eram tão profundas e tão cuidadosamente incentivadas [...]". (OLIVEIRA, 1988, p. 41).

Márcio Soares (2006, p. 278) afirma que ter um escravo era um importante símbolo de mobilidade social, considerando que muitas pessoas "tidas como brancas" não tiveram acesso à posse 
de cativos. Analisando testamentos em Campo dos Goitacases, o autor afirma ainda que "a posse de escravos assumia uma grande relevância no conjunto das fortunas inventariadas", pelo fato de tal posse representar recurso econômico e pelo caráter político "que esse tipo de propriedade assumia nos processos de hierarquização social, entre os próprios descendentes de escravos". Para o autor, este tipo de propriedade "singular" contribuía, inclusive, para acelerar "o processo de distanciamento do (ante) passado escravo, na medida em que transformava pessoas, direta ou indiretamente egressas do cativeiro, em senhoras de almas." (SOARES, 2006, p. 278).

Sheila Faria destaca que, em vários estudos sobre a riqueza no período escravista, "a posse de escravos é um indicativo importante para inferir o grau de fortuna dos envolvidos”, além do prestígio social que poderia ser alcançado. Todavia, apesar do papel da posse nesta sociedade, "a aquisição de um escravo não era fácil". Comprar pelo menos um cativo exigia, da grande parcela da população, um esforço econômico significativo. A autora levanta uma questão interessante em torno da afirmação de que a posse de um único escravo seria um indicativo da pobreza de um proprietário. Faria discorda, afirmando que este dado não pode ser considerado de forma absoluta, "principalmente porque a grande maioria da população economicamente ativa da sociedade escravista não tinha condições de ter nem mesmo um". E diz ainda: "Mulheres proprietárias de escravos, qualquer que tenha sido sua condição social, não podem ser consideradas 'pobres', no sentido econômico do termo." (FARIA, 2000, p. 83).

Estas questões apontadas pelos autores nos intrigam ainda mais, quando pensamos em escravos senhores de escravos. Se, para um liberto, não havia qualquer "constrangimento" em possuir escravos (até porque era algo legítimo na sociedade de então), percebemos que o mesmo se aplicava aos cativos-senhores, o que não deixa de ser algo no mínimo surpreendente. Pensar em um cativeiro dentro do cativeiro assombraria os antigos defensores da passividade dos escravos, e nos deixa mais perguntas do que respostas. 
Um ponto importante está no fato de que grande parte da população livre e liberta não tinha condições materiais de comprar nem sequer um escravo, enquanto cativos beneditinos tinham dois, três ou até nove escravos em seu poder. Poder, eis uma questão que fazia parte do cotidiano destes sujeitos. Prestígio social? Possivelmente. Apenas dentro ou também fora das propriedades em que viviam? Como eram vistos estes senhores pela vizinhança pobre e não-proprietária? Como se dava o processo de hierarquização social? Ter a liberdade, mas ser pobre, significava um status superior a um escravo proprietário? Se ter um cativo, enquanto liberto, poderia significar um importante passo no processo de distanciamento do (ante) passado escravo, o que dizer daqueles que se mantiveram em cativeiro, mas como senhores escravistas?

Concordamos com Vanessa Ramos quando afirma que esses exemplos de transação pela liberdade entre senhores e cativos "reforçam ainda mais a participação direta dos escravos, caracterizando-os como agentes sociais que interagiam de forma bem ativa na sociedade em que viviam." (RAMOS, 2007, p. 34).

\section{Referências}

ALMEIDA, Kátia Lorena Novais. Alforrias em Rio de Contas. Bahia, século XIX. 2006. 174 f. Dissertação (Mestrado em História) - Programa de Pós-Graduação em História Social, Universidade Federal da Bahia, Salvador, 2006.

ARAÚJJ, Maria das Graças Aires de. Decadência e restauração da Ordem Carmelita em Pernambuco (1759-1923). 2007. 198f. Tese (Doutorado em História) - Programa de Pós-Graduação em História, Universidade Federal de Pernambuco, Recife, 2009.

CERTEAU, Michel de. A invenção do cotidiano: 1. artes de fazer. Petrópolis: Vozes, 1994.

CHALHOUB, Sidney. Visões da liberdade: uma história das últimas décadas da escravidão na Corte. São Paulo: Companhia das Letras, 1990. 
COSTA, Robson Pedrosa. A Ordem de São Bento e os escravos do Santo, Pernambuco, séculos XVIII e XIX". 2013. 286 f. Tese (Doutorado em História) - Programa de Pós-Graduação em História, Universidade Federal de Pernambuco, Recife, 2013.

COSTA, Robson Pedrosa. Um senhor de escravo em cativeiro: a trajetória de Nicolau de Souza, 1812-1835. Territórios \& Fronteiras, Cuiabá, v. 10, n. 1, p. 47-66, jan./jul., 2017.

COSTA, Valéria Gomes. Trajetórias negras: Os libertos da Costa d'África no Recife (1846-1890). 2013. 251 f. Tese (Doutorado em História) Programa de Pós-Graduação em História, Universidade Federal de Pernambuco, Recife, 2013.

DAVIS, Natalie Zemon. O retorno de Martin Guerre. Rio de Janeiro: Paz e Terra, 1987.

EISENBERG, Peter L. Homens esquecidos: escravos e trabalhadores livres no Brasil, séculos XVIII e XIX. Campinas: Ed. da Unicamp, 1989.

FARIA, Sheila de Castro. Mulheres forras: riquezas e estigma social. Tempo, Rio de Janeiro, n. 9, p. 65-92, 2000.

FLORENTINO, Manolo GOES, José Roberto. A paz nas senzalas: famílias escravas e tráfico atlântico, Rio de Janeiro, c. 1790-c.1850. Rio de Janeiro: Civilização Brasileira, 1997.

GINZBURG, Carlo. O nome e o como. In: GINZBURG, Carlo. A microhistória e outros ensaios. Rio de. Janeiro: Bertrand Brasil, 1989. p.169178.

GINZBURG, Carlo. O queijo e os vermes: o cotidiano e as ideias de um moleiro perseguido pela Inquisição. São Paulo: Companhia das letras, 2006.

GOLDSCHMIDT, Eliana Rea. A carta de alforria na conquista da liberdade. IDE, São Paulo, v. 33, n. 50, p. 114-125, jul. 2010.

GRAHAN, Sandra Lauderdale. Caetana diz não: histórias de mulheres da sociedade escravista brasileira. São Paulo: Companhia das Letras, 2005.

KARASCH, Mary. A vida dos escravos no Rio de Janeiro. São Paulo: Companhia das Letras, 2000. 
LARA, Silvia Hunold. 'Blowin' in the wind. E. P. Thompson e a experiência negra no Brasil. Projeto História, São Paulo, n. 12, 1995.

LARA, Silvia Hunold; MENDONÇA, Joseli Maria Nunes. Direitos e justiça no Brasil: ensaio sobre História Social. Campinas: Editora da UNICAMP, 2006.

LEVI, Giovanni. Sobre a Micro-História. In: BURKE, Peter (Org.). A escrita da História: novas perspectivas. São Paulo: Editora da Universidade Estadual Paulista, 1992. p.133-162.

LIMA, Maria da Vitória Barbosa. Liberdade interditada, liberdade reavida: escravos e libertos na Paraíba escravista (século XIX). 2010. 378 f. Tese (Doutorado em História) - Programa de Pós-Graduação em História, Universidade Federal de Pernambuco, Recife, 2010.

LIMA, Tatiana Silva. O nós que alforriam: relações sociais na construção da liberdade, Recife, décadas de 1840 e 1850. 2004. 156f. Dissertação (Mestrado em História) - Programa de Pós-Graduação em História, Universidade Federal de Pernambuco, Recife, 2004.

MALHEIROS, Agostinho Marques Perdigão. A escravidão no Brasil: ensaio histórico-jurídico-social. Rio de Janeiro: Typographia Nacional, 1866.

MANUSCRITOS do Arquivo do Mosteiro de São Bento de Olinda. Revista do Instituto Arqueológico, Histórico e Geográfico Pernambucano, v. XLII, 1948-1949 (1952).

MARQUESE, Rafael Bivar de. Feitores do corpo, missionários da mente: senhores, letrados e o controle dos escravos nas Américas, 166-1860. São Paulo: Companhia das Letras, 2004.

MARQUESE, Rafael de Bivar de. As desventuras de um conceito: capitalismo histórico e a historiografia sobre a escravidão brasileira. Revista de História, São Paulo, n. 169, p. 223-253, jul./dez. 2013.

MATTOS, Hebe Maria. Das cores do silêncio: os significados da liberdade no Sudeste escravista, Brasil, século XIX. Rio de Janeiro: Nova Fronteira, 1998. 
MATTOSO, Kátia M. Queirós. A carta de alforria como fonte complementar para o estudo da rentabilidade da mão-de-obra escrava urbana (18191888). In: PELÁES, Carlos Manoel; BUESCU, Mircea. A moderna história econômica. Rio de Janeiro: Apec, 1976. p.149-168.

MIEKO, Nishida. As alforrias e o papel da etnia na escravidão urbana: Salvador, Brasil, 1808-1888. Estudos Econômicos, v. 23, n. 2, p. 227265, 1993.

MOLINA, Sandra Molina. A morte da tradição: a Ordem do Carmo e os escravos da santa contra o Império do Brasil (1850-1889). 2006. Tese (Doutorado em História) - Programa de Pós-Graduação em História Social, Universidade de São Paulo, São Paulo, 2006.

NEDER, Gizlene et al. Os estudos sobre a escravidão e as relações entre a História e o Direito. Tempo, Rio de Janeiro, v. 3, n. 6, dez. 1998.

OLIVEIRA, Maria Inês Côrtez de. O liberto: seu mundo e os outros, Salvador, 1790/1890. São Paulo: Corrupio, 1988.

OLIVEIRA, Nelson Henrique Moreira de. Forros Senhores da Freguesia de Nossa Senhora da Piedade do Iguaçu. Fins do Século XVIII. 2010. Dissertação (Mestrado em História) - Programa de Pós-Graduação em História, Universidade Federal Rural do Rio de Janeiro, Seropédica, 2010.

PACHECO, Paulo Henrique Silva. Moral e disciplina: monges e escravos no espaço monástico beneditino na Corte Imperial. 2010. Dissertação (Mestrado em História) - Programa de pós-Graduação em História, Universidade do Estado do Rio de Janeiro, Rio de Janeiro, 2010.

PAIVA, Eduardo França. Escravos e libertos nas Minas Gerais do século $X V I I I$ : estratégias de resistência através dos testamentos. São Paulo: Annablume, 1995.

PIRATININGA JÚNIOR, Luiz Gonzaga. Dietário dos Escravos de São Bento: originários de São Caetano e São Bernardo. São Paulo: HUCITEC; São Caetano do Sul: Prefeitura, 1991.

RAMOS, Vanessa Gomes. "Os escravos da religião". Alforriandos do clero católico no Rio de Janeiro Imperial (1840-1871). 2007. Dissertação (Mestrado em História) - Programa de Pós-Graduação em História Social, Universidade Federal do Rio de Janeiro, Rio de Janeiro, 2007. 
REIS, João José. Domingos Sodré, um sacerdote africano: escravidão, liberdade e candomblé na Bahia do século XIX. São Paulo: Companhia das Letras, 2008.

REIS, João José. De escravo a rico liberto: a trajetória do africano Manoel Joaquim Ricardo na Bahia oitocentista. Revista História, São Paulo, n. 174, p. 15-68, jan./jul. 2016.

REVEL, Jacques (Org.). Jogos de escalas: a experiência da microanálise. Rio de Janeiro: Editora Fundação Getúlio Vargas, 1998.

SANTOS, Jocélio Teles dos. De pardos disfarçados a brancos pouco claros: classificações raciais no Brasil dos séculos XVIII-XIX. Afro-Ásia, Salvador, v. 32, p. 115-137, 2005.

SCHWARTZ, Stuart. Escravos, roceiros e rebeldes. Bauru: EDUSC, 2001.

SLENES, Robert W. Na senzala, uma flor: esperanças e recordações na formação da família escrava, Brasil, Sudeste, século XIX. Rio de Janeiro: Nova Fronteira, 1999.

SLENES, Robert W. Senhores e subalternos no oeste paulista. In: ALENCASTRO, Luiz Felipe (Org.). História da vida privada no Brasil. v. 2: Império: a corte e a modernidade nacional. São Paulo: Companhia das Letras, 1997. p. 233-290.

SOARES, Carlos Eugenio Líbano. "Instruído na fé, batizado em pé": batismo de africanos na Sé da Bahia na $1^{\text {a }}$ metade do século XVIII, 1734-1742. Afro-Ásia, Salvador, v. 39, p. 79-113, 2010.

SOARES, Márcio de Sousa. A remissão do cativeiro: alforrias e liberdades nos Campos dos Goitacases, c. 1750 - c. 1830. 2006. Tese (Doutorado em História) - Programa de Pós-Graduação em História, Universidade Federal Fluminense, Niterói, 2006.

SOUZA, Jorge Victor Araújo. Para além do claustro: uma história social da inserção beneditina na América Portuguesa, c. 1580-c.1690. 2011. Tese (Doutorado em História) - Programa de Pós-Graduação em História, Universidade Federal Fluminense, Niterói, 2011. 
SOUZA, Jorge Victor de Araújo. Monges negros: trajetórias, cotidiano e sociabilidade dos beneditinos no Rio de Janeiro - século XVIII.2007. Dissertação (Mestrado em História) - Pós-Graduação em História Social, Universidade Federal do Rio de Janeiro, Rio de Janeiro, 2007.

TAVARES, Cristiane. Ascetismo e colonização: o labor missionário dos beneditinos na América Portuguesa (1580-1656). 2007. Dissertação (Mestrado em História) - Pós-Graduação em História, Universidade Federal do Paraná, Curitiba, 2007.

THOMPSON, E.P. Costumes em Comum: estudos sobre a cultura popular tradicional. São Paulo: Companhia das Letras, 1998.

ZERO, Arethuza Helena. Escravidão e liberdade: as alforrias em Campinas no século XIX (1830-1888). 2009. Tese (Doutorado em História Econômica) - Programa de Pós-Graduação do Instituto de Economia da UNICAMP, Campinas, 2009.

Recebido em agosto de 2016. Aprovado em setembro de 2017. 